\title{
Microscopic Investigation on Fungal Pigment Formation and its Morphology in Wood Substrates
}

\author{
Daniela Tudor ${ }^{1}$, Sara C. Robinson ${ }^{1, *, \#}$, Tammy L. Sage ${ }^{2}$, Sally Krigstin ${ }^{1}$ and Paul A. Cooper ${ }^{1}$ \\ ${ }^{1}$ University of Toronto, Faculty of Forestry, 33 Willcocks St., Toronto, ON M5S 3B3, Canada \\ ${ }^{2}$ University of Toronto, Department of Ecology and Evolutionary Biology, 25 Willcocks St., Toronto, ON M5S 3B2, \\ Canada
}

\begin{abstract}
Melanin formation and assembly by fungi has largely been investigated mainly for its importance in pathogenesis, as well as to establish the functions and biosynthetic pathways of melanin formed during the process of successional wood decay. It is known that melanin formation varies based on fungal species, especially melanin produced by ascomycetes versus basidiomycetes, and that the mechanisms of melanin production by basidiomycetes are more complex and thus far not entirely elucidated. This study compares in vivo melanin formation by Oxyporus populinus in sugar maple and Fomes fomentarius in birch, and in vitro pigmentation by Trametes versicolor, Xylaria polymorpha and Inonotus hispidus in sugar maple and beech, with and without the influence of the melanin precursor, catechol. The results of this research indicate a bi- or multi-modal activity of melanin production and assembly by wood decay fungi, and identify possible variations in melanin formation mechanisms as influenced by fungal and wood species.
\end{abstract}

Keywords: Fungi, Inonotus hispidus, melanin, spalting, Trametes versicolor, Xylaria polymorpha.

\section{INTRODUCTION}

Fungal pigmentation in zone lines of spalted wood produced by various decay fungi can vary in structure, formation, and significance. While accounts of fungal melanin deposition in various wood species in the literature are numerous, some of the most interesting effects of hyphal melanin can be seen in the characterization of an individual fungus under controlled growing conditions [1-3].

The macro structure of such fungal melanin production has been well studied. The black fungal melanins have been identified in many developmental stages, such as sclerotial formation, sporogenesis, and hyphal pigmentation due to wounding or as result of light exposure and extreme environmental conditions. It was demonstrated that the melanins formed by wood inhabiting fungi such as Xylaria polymorpha (Pers.) Grev, Armillaria mellea (Vahl) P. Kumm and Polyporus squamosus (Huds.) Fr. are contained in compacted black bladder-like hyphae found in the lumen of wood cells that are practically unaltered, and that this matrix of black hyphae forms a compact amorphous structure [4-6].

The ultrastructure of melanin formation within fungal cells is less well studied, although there are standard and modified protocols for electron and fluorescence

\footnotetext{
*Address correspondence to this author at the University of Toronto Faculty of Forestry, 33 Willcocks St., Toronto, ON M5S 3B3, Canada;

E-mail: sara.robinson@oregonstate.edu
}

\#Current Address: Department of Wood Science and Engineering, Oregon State University, 119 Richardson, Corvallis, OR 97331, USA microscopy, as described by Wheeler et al. [7], Casadevall et al. [8] and Butler et al. [3]. However, such studies often inferred that the high density of melanin pigments provides sufficient contrast for electron microscopy of unstained biological samples such that standard preparation techniques may not be relevant [9-11].

Despite the issues surrounding the study of melanin ultrastructure, ultrastructure studies have been performed by Ellis and Griffiths [12], who studied melanized mycelium of Verticillium dahliae Kleb., Humicola grisea Traaen, Epicoccumnigrum Link, Colletotrichum coccodes (Wallr.) S. Hughes and Amorphotheca resinae Parbery. The study revealed that fungal melanin produced in cultures is confined to the fungus cell wall region, either externally or within the hyphal or spore cell walls. In some cases, the accumulation of electron-opaque granules of melanin was associated with varicose excrescences that varied in size from 30 to $200 \mathrm{~nm}$. Further imaging investigations with TEM and Scanning Electron Microscopy (SEM) on melanin formation of Phomopsis spp. exposed to short periods of light revealed similar structural characteristics [13].

Based on similarities in the ultrastructure of melanin formation between a wild type isolate and a scytalone-treated albino mutant of $V$. dahliae, Wheeler et al. [7] concluded that scytalone is a natural melanin precursor, as previously reported by Bell et al. [14]. Light and electron microscopy revealed that granular melanin occurred within the sclerotial cell walls, forming a matrix that encased the fungal walls of the wild type isolate as well as those of the albino mutant when treated with scytalone. However, the melanin produced by the mutant treated with catechol, dihydroxyphenylalanine (DOPA), and other phenols, showed different properties than 
that of the wild type or scytalone melanins. While the surfaces of sclerotial hyphae of the wild-type isolate appeared rough due to dense melanin granule formations, the surfaces of the albino mutant and mutants treated with melanin precursors were relatively smooth.

Melanin biofilm formations involved in sporogenesis of Agaricus bisporus (J.E. Lange) Imbach were studied by Hegnauer et al. [15]. TEM studies of melanin extracted from spores indicated the presence of two types of melanin structure: partly amorphous and partly granular plate-like particles $50-100 \mathrm{~nm}$ in diameter, and electron-opaque round $30-200 \mathrm{~nm}$ particles. Wheeler and Bell [16] identified three types of melanin formation: wall-bound, extracellular and cytoplasmic melanins; the last type was identified only in Aspergillus niger Tiegh., and was thus far less common, while wall-bound and extracellular melanins were formed by most of the studied fungi, regardless of the nature of the phenolic precursors used for melanin biosynthesis. Evidence on the melanin nature of the electrondense materials in fungal cell walls was also reported by Bell and Wheeler [2]. Electron-dense granules were observed only in pigmented cells and not in hyaline fungal cells. Also, normal patterns of electron-dense granule formations appeared when melanin precursors were available to albino mutants. Moreover, the introduction of the melanin synthesis inhibitor, tricyclazole, affected electron-dense granule formation in several fungal species tested that produced 1,8 dihydroxynaphthalene (DHN) melanin, mostly characteristic of ascomycetes fungi [2].

A quantitative assay of cell wall melanin was developed by Butler and Lachance [17], based on the high affinity of Azure A dye for DHN and DOPA melanin, as previously described by Bull [18] and Nicolaus et al. [19]. Although the procedure was sensitive, nondestructive and rapid (30 min), the range of linearity of the azure A method was narrower when assessing whole cells of the black yeast Phaeococcomyces nigricans (M.A. Rich \& A.M. Stern) de Hoog compared to the extracted and digested melanin of the same fungus.

A technique of melanin localization was developed using the enhanced accumulation of DHN melanin in cell walls of the rice plant pathogen Gaeumannomyces graminis var. graminis (Sacc.) Arx \& D.L. Olivier, exposed to copper sulfide [20]. Since considerable amounts of copper sulfide were absorbed in the melanin layer, a sulfide-silver staining technique proved successful for visualization and localization of copper sulfide associated with the melanin layer of fungal cell walls. Silver also precipitates in hyphal septa, which suggests that septa also melanize, and silver precipitation does not occur near hyphal tips or in tricyclazole-treated hyphae or their septa. These findings are in agreement with previous research by Henson et al. [21] and Butler and Lachance [17], who also observed the binding of Azure A dye to the septa of melanized hyphae of G. graminis. A copper sulfide-silver staining technique for fungal melanin detection in electron microscopy was further developed by Butler et al. [3] and proved to be more efficient in labeling melanin produced in the black yeast Phaeococcomyces, in the G. graminis var. graminis, and in the sporidial cells of Microbotryum violaceum (Pers.) G. Deml \& Oberw.
Research on the antibody response to melanin precursors and pheomelanin was reported by Kammeyer et al. [22] and Liu and Jimbow [23]. The immune response of fungal melanin was first investigated in the human pathogen Cryptococcus neoformans (San Felice) Vuill by Casadevall and Scharff [24]. When grown on phenolic media, the basidiomycetes $C$. neoformans produced black pigmentation that formed a protective capsule for the cells [25]. Research on melanin contribution to virulence of this fungus led to the investigation of the binding capacity of an anti-melanin monoclonal antibody to glucuronoxylomannan (GXM) [26]. GXM was determined as the major polysaccharide component of capsular C. neoformans [27], and the antibody response was evaluated by enzyme-linked immunosorbent assay (ELISA), immunofluorescence and agglutination analysis [28]. Beside serological methods used to study the antibody response to melanin, phage display techniques were also used to identify melanin-binding peptides for $C$. neoformans [29] and for Alternaria alternata (Fr.) Keissl. [30].

The effectiveness of several melanin antibodies generated in response to polymerized fungal melanin $\mathrm{MAb}$ 11B11, 6D2 and 5C11, was studied by Rosas et al. [11]. These were tested against L-dopa melanin from $C$. neoformans, synthetic melanin, and melanin from Sepia officinalis L. (ink melanin). The results indicated MAb 6D2 as the most reliable antibody. Moreover, immunogold electron microscopy indicated that the MAb 6D2 and 11B11antibodies have more than one binding site to melanins [8, 11, 31-33].

This research investigates fungal pigment deposition within wood cells by various spalting fungi and aims to help elucidate some important factors that might influence and specify pigmentation patterns in spalted wood. Our studies compare pigment formation by various fungi in the same wood substrate, or by one fungus in various wood substrates. The results of this research will aid in understanding the mechanisms of spalting by specific melanin-producing fungi, so that commercialization of controlled spalting processes [34] can be more readily achieved.

\section{MATERIALS AND METHODS}

\section{Wood and Fungal Species}

Wood samples of three species (Acer saccharum Marsh sugar maple; Fagus grandifolia Ehrh. - beech and Betula papyrifera Marshall - birch) colonized by one of five species of spalting fungi, were studied (Table 1). The specimens were acquired from natural or in vitro spalted wood samples, from a particular zone of the samples that displayed zone line formation or concentrated stain pigmentation. Fungi used in in vitro experiments were grown on $95 \times 15 \mathrm{~mm}$ Petri dishes with $2 \%$ malt extract agar at $21{ }^{\circ} \mathrm{C}$ for two weeks prior to wood inoculation. In addition, sugar maple and beech samples pretreated in vacuum with catechol (Sigma-Aldrich) and L-dopa (Sigma-Aldrich) melanin precursors for $100 \mathrm{ppm}$ retention before fungal inoculation were also investigated for pigmentation. 
Table 1. Substrate and fungal species selection for microscopy analysis.

\begin{tabular}{|c|c|c|}
\hline Substrate & Fungal Species/ Spalting Condition & Investigation Method \\
\hline Sugar maple & $\begin{array}{c}\text { Oxyporus populinus(wild)/in vivo } \\
\text { Trametes versicolor }(\mathrm{Mad} 697) / \text { in vitro } \\
\text { Xylaria polymorpha }(\mathrm{UAMH} 11520) / \text { in vitro } \\
\text { Inonotus hispidus }(\mathrm{F} 2037) / \text { in vitro }\end{array}$ & $\begin{array}{l}\text { LM, TEM, SEM, FL, CM } \\
\text { TEM, FL } \\
\text { TEM, FL } \\
\text { TEM }\end{array}$ \\
\hline Beech & $\begin{array}{c}\text { Trametes versicolor }(\mathrm{Mad} 697) / \text { in vitro } \\
\text { Xylaria polymorpha }(\mathrm{UAMH} 11520) / \text { in vitro } \\
\text { Inonotus hispidus }(\mathrm{F} 2037) / \text { in vitro }\end{array}$ & $\begin{array}{l}\text { TEM, FL } \\
\text { TEM, FL } \\
\text { TEM }\end{array}$ \\
\hline Birch & Fomes fomentarius(wild)/ in vivo & TEM, FL \\
\hline
\end{tabular}

\section{Chemical Fixation for Copper Sulfide-silver Staining Technique}

Wood sections of $1-2 \mu \mathrm{m}$ were treated with a $10 \mathrm{mM}$ copper sulfate solution in distilled water for $1-10$ hours, and after washing were treated with $1 \%$ sodium sulfide solution in distilled water for 1 hour in the dark. After another series of washing with distilled water, the samples were dried and developed in a $20 \mathrm{~mL}$ solution of $22 \mathrm{mg}$ silver lactate and $170 \mathrm{mg}$ hydroquinone in a citrate buffer for $1-10 \mathrm{~min}$ at $26^{\circ} \mathrm{C}$, fixed in $2 \%$ glutaraldehyde in phosphate buffer, and examined with an Axioplan light microscope with a DP71 camera.

\section{Chemical Fixation for SEM}

Spalted wood sections of $1-5 \mu \mathrm{m}$ were suspended overnight in a primary fixative of $2.5 \%$ glutaraldehyde in $0.1 \mathrm{M}$ phosphate. After washing two times with $0.1 \mathrm{M}$ phosphate for $5 \mathrm{~min}$, they were post-fixed in $1 \%$ osmium tetroxide in $0.1 \mathrm{M}$ phosphate for 1 hour in the dark, followed by ethanol dehydration at 30, 50, 70, 80 and $90 \%$ for $10 \mathrm{~min}$ and $100 \%$ three times for $15 \mathrm{~min}$. Hexamethyldisiloxane (HMDS) infiltration was accomplished by immersion of the specimens in different concentration over a certain period of time: 1:3 HMDS:100\% EtOH for $30 \mathrm{~min}, 1: 1 \mathrm{HMDS}: 100 \%$ $\mathrm{EtOH}$ overnight, 3:1 HMDS:100\% EtOH for $30 \mathrm{~min}$, and $100 \%$ HMDS three times for $60 \mathrm{~min}$. The samples were dried overnight in a fume hood. The specimens were mounted on aluminum stubs with double-sided carbon tape and sputter coated with gold-palladium using a Cressington Sputter Coater 108. The examination was performed on a Hitachi S2500 SEM at $20 \mathrm{kV}$.

Alternative specimen preparation omitted fixation and post-fixation with osmium, and included coating with goldpalladium for critical point dried samples.

\section{Chemical Fixation for TEM and LM}

Samples of spalted wood were fixed overnight in $2.5 \%$ (alternative 2\%) glutaraldehyde and post-fixed in $1 \%$ osmium tetroxide for 1 hour (alternative overnight at $4{ }^{\circ} \mathrm{C}$ or omitted) in the dark. After dehydration with ethanol, the samples were embedded in Spurr's resin in a flat mould and the resin was polymerized overnight at $63-65^{\circ} \mathrm{C}$.
For LM imaging, the embedded samples were sectioned with a glass knife in semi-thin sections and examined with an Olympus MVX10 microscope equipped with aDP71 camera.

Ultrathin sections were stained with 3\% uranyl acetate for $45 \mathrm{~min}$ in the dark and post-stained with Reynold's lead citrate for $15 \mathrm{~min}$. Stained and unstained sections were examined with a Philips PW6006 TEM.

\section{Immunolocalization Procedure for TEM}

To localize antibody binding on fungal melanins in vivo and in vitro, immunogold labeling was performed on spalted wood tissue. Ultrathin tissue sections of samples embedded in LR white resin were placed on nickel grids with Formvar film, treated with $10 \% \mathrm{H}_{2} \mathrm{O}_{2}$ for $10 \mathrm{~min}$., and then washed with phosphate buffered saline (PBS) solution. Grids were blocked in Super Block Blocking Buffer (Thermo Scientific) in PBS for 4 hours at room temperature. Grids were then incubated overnight at $4{ }^{\circ} \mathrm{C}$ in $5 \mu \mathrm{g} / \mathrm{ml}$ of MAb 6D2, kindly provided by Dr. Arturo Casadevall (Albert Einstein College of Medicine, Bronx, NY). After being washed with PBS, the grids were incubated in secondary antibody at 1:1,000 dilution of immunogold conjugate for electron microscopy (EM), containing goat anti-mouse immunoglobulin M (IgM): $5 \mathrm{~nm}$ (BBI International) for $2 \mathrm{~h}$ at room temperature. Grids were then washed with PBS, fixed in $2 \%$ glutaraldehyde, and examined using a 100 CX Philips EM 201 (PW6006) TEM with AMT V600 software.

\section{Immunolocalization Procedure for SEM}

To identify cell wall-bound fungal melanin particles, samples of sound wood (control) and wood with melanin formation of $5 \mu \mathrm{m}$ thickness were fixed in $1.25 \%$ glutaraldehyde overnight at $4{ }^{\circ} \mathrm{C}$, blocked for nonspecific binding with PBS $+4 \%$ (1\%) BSA (alternately added 4-1\% milk) for 1 hour, incubated for $30 \mathrm{~min}$ to 3 hours in $20 \mu \mathrm{g} / \mathrm{ml}$ MAb 6D2 in PBS, treated after a washing series with $10 \mathrm{~nm}$ protein A-gold (1:100) for 1hour, and (alternatively) exposed to silver enhancement reagent (SEKL15 from BBI) for 5 $20 \mathrm{~min}$. After washing and drying, samples were coated with gold-palladium and examined with a Hitachi S2500 SEM. Control samples were used to test each step of the procedure, including alternatives. 
Wood samples $5 \mu \mathrm{m}$ thick, fixed in $1.25 \%$ glutaraldehyde overnight at $4{ }^{\circ} \mathrm{C}$, were blocked for nonspecific binding with PBS $+4 \%(1 \%)$ BSA for 1 hour, incubated for 3 hours in $20 \mu \mathrm{g} / \mathrm{ml} \mathrm{MAb} 6 \mathrm{D} 2$ in PBS, treated after a washing series with immunogold conjugate EM Goat antibody mouse IgM:5nm (BBI International) 1:100 for 1 hour, and alternatively, and exposed to silver enhancement reagent (SEKL15 from BBI) for 5 - $20 \mathrm{~min}$. After washing and drying, samples were coated with gold-palladium and examined with a Hitachi S2500 SEM.

\section{Immunofluorescence Analyses of Spalted Wood.}

Thin sections $0.5-1 \mu \mathrm{m}$ of spalted wood samples and sound wood (control) embedded in LR white resin, were first immersed in Super Block Blocking Buffer in PBS for 4 hours at room temperature, and incubated with $20 \mu \mathrm{g} / \mathrm{ml}$ of MAb 6D2 overnight at $4{ }^{\circ} \mathrm{C}$, followed by conjugation to the Alexa Fluor 488 Goat anti mouse I gM ( $\mu$ chain) (Invitrogen) 1:200. Tissue samples were washed in PBS. A mounting solution of $50 \%$ glycerol, $50 \%$ PBS and $0.1 \mathrm{MN}$ propyl gallate (P3130 Sigma -Aldrich) was applied and samples were covered with a cover slip. Samples were examined with an Axioplan microscope with fluoresce in isothiocyanate filter, Olympus DP71 camera and Quorum Wave FX / FRAP spinning disk confocal microscope.

\section{RESULTS}

The black pigments produced in vivo by Oxyporus populinus and Fomes fomentarius and in vitro by Trametes versicolor, Xylaria polymorpha, and Inonotus hispidus in wood substrates were immunolabeled by the MAb 6D2 melanin antibody.

Sugar maple samples with zone line formations by $O$. populinus were analyzed by LM, SEM, TEM, fluorescence and confocal microscopy. The apparent black line formation was composed of dense mycelium that filled the lumen of the wood cells (Fig. 1A, E). Two types of melanin deposits were distinguished. The first type was a dense layer of oval melanin granules of $50-100 \mathrm{~nm}$, deposited in the cavities characteristic of white rot fungi along the decayed wood cell wall (Fig. 1B, C, single white arrow). Within this layer, round and bigger granules of melanin up to $1.5 \mu \mathrm{m}$ in diameter and with rugose surfaces were also often observed in well established zone line formations (Fig. 1B,C, double white arrows). The second type of melanin deposit was observed in sclerotial fungal hyphae that colonized the wood lumens, and formed conglomerates of hollow hyphae (Fig. 1B, E, F, red double arrows) with rugose surfaces (Fig. 1D, red arrows). Hyphae of $2-5 \mu \mathrm{m}$ in diameter with $500-600 \mathrm{~nm}$ melanized wall thickness tended to completely fill the wood cells in the zone lines of spalted wood. Fluorescence imaging revealed that the MAb 6D2 antibody bound selectively to melanin deposits from wood cells. The melanin exposed by sectioning wood cells partially or totally obstructed by dense black sclerotial mycelium (Fig. 2) was not always labeled by the melanin antibody (Fig. 3A, B - arrow).
The studied samples of birch with black zone lines formed by $F$. fomentarius had no extracellular layer of melanin deposits along the wood cell wall. The zone lines were comprised of melanized fungal hyphae within the wood cells. Although the melanin is mostly found within the fungal cell, melanin immunolabeling was registered also at the cell wall level (Fig. 4A, B and $\mathbf{C}-$ arrow).

The investigated melanin pigments formed by $T$. versicolor showed morphological differences between sugar maple and beech substrate, and no differences in the same wood substrate treated or untreated with catechol before fungal inoculation (Fig. 5A, B and Fig. 6A, B). In sugar maple, small melanin granules of $100-250 \mathrm{~nm}$ released by active hyphae tended to assemble without much initial binding to the cell wall, whereas beech cell walls and hyphal surroundings were heavily coated with a dense layer of melanin deposits (Fig. 5 and Fig. 6).

Similar types and sizes of oval melanin granules were observed in the case of $X$. polymorpha, 50-150nm in sugar maple (Fig. 7A, C and E), and $70-150 \mathrm{~nm}$ in beech (Fig. 7B, $\mathbf{D}$ and $\mathbf{F}$ ), that assembled from thin layer deposition on the cell wall of the wood vessels (Fig. 7G) to dense conglomerates of melanized mycelium within the inner wood cell walls (Fig. 7H). Heavy melanized fungal hyphae appeared hollow in section, with rugose surface (Fig. 7Harrow).

Pigmentation produced by $I$. hispidus was observed as deposition of small granules, $100-200 \mathrm{~nm}$, along the wood cell walls in sugar maple (Fig. 8A - arrow) along with dense bigger granules $(300-850 \mathrm{~nm})$ (Fig. 8A - double arrows). The melanin granule depositions were not present in wood cells subject to active fungal decomposition (Fig. 8B). Melanin production was immunolabeled within the fungal hyphae as well as in their cell walls (Fig. 8C, red arrow).

\section{DISCUSSION}

Fungal melanin formations cannot be easily differentiated among fungal species, especially when produced in various substrates. However, two distinctive characteristics of pigment assembly, the granule-dense layer attached to the wood cell lumen walls, and the conglomeration of sclerotial hyphae that tend to obstruct wood cell lumina, are present in most melanized woodinhabiting fungi, with variation in granule dimensions and assembly patterns (Table 2). The differences in pigment assembly might be reflected in the diversity of the functions of melanin protection. We observed that the layer of extracellular melanin granules deposited along the wood cells might be the initial stage of zone line formation in spalted wood. The complete obstruction of successive wood cells at the boundaries of each fungal colony is comprised of melanized hyphae that form a dense outer layer. This layer ensures the protection of fungal colonies, including the establishment of a secure territory and food source, and resistance to fungal competitors. The extracellular melanins that form the deposits along the wood cell walls are derived either from secretion of phenol oxidases into the external environment to oxidize available phenolic compounds, or by 

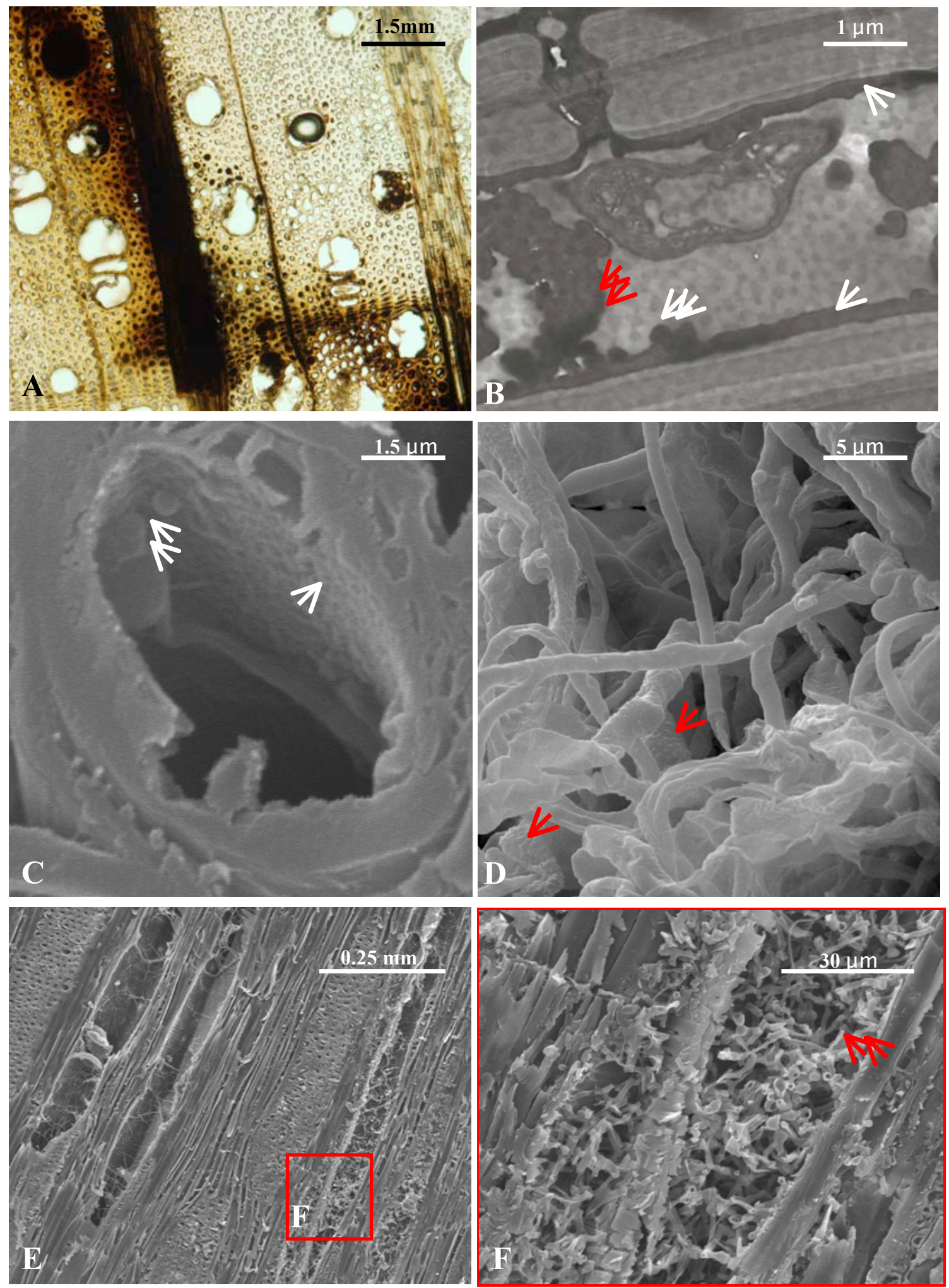

Fig. (1). Acer saccharum samples with zone lines formations by Oxyporus populinus; (A) LM of wood cross section with melanized mycelium filling the lumen of the wood cells; (B) TEM of parenchyma ray in longitudinal section, melanized mycelium organized in clusters (red double arrows); (C) SEM of wood vessel with melanized mycelium; small oval melanin granule deposits (white single arrows); round and bigger granules of melanin, (double white arrows); (D) SEM of melanised mycelium, rugose surface of the outer wall of melanized mycelium (red single arrows); (E and F) SEM of tangential section in wood sample; melanized mycelium organized in clusters in vessels (red double arrows). 

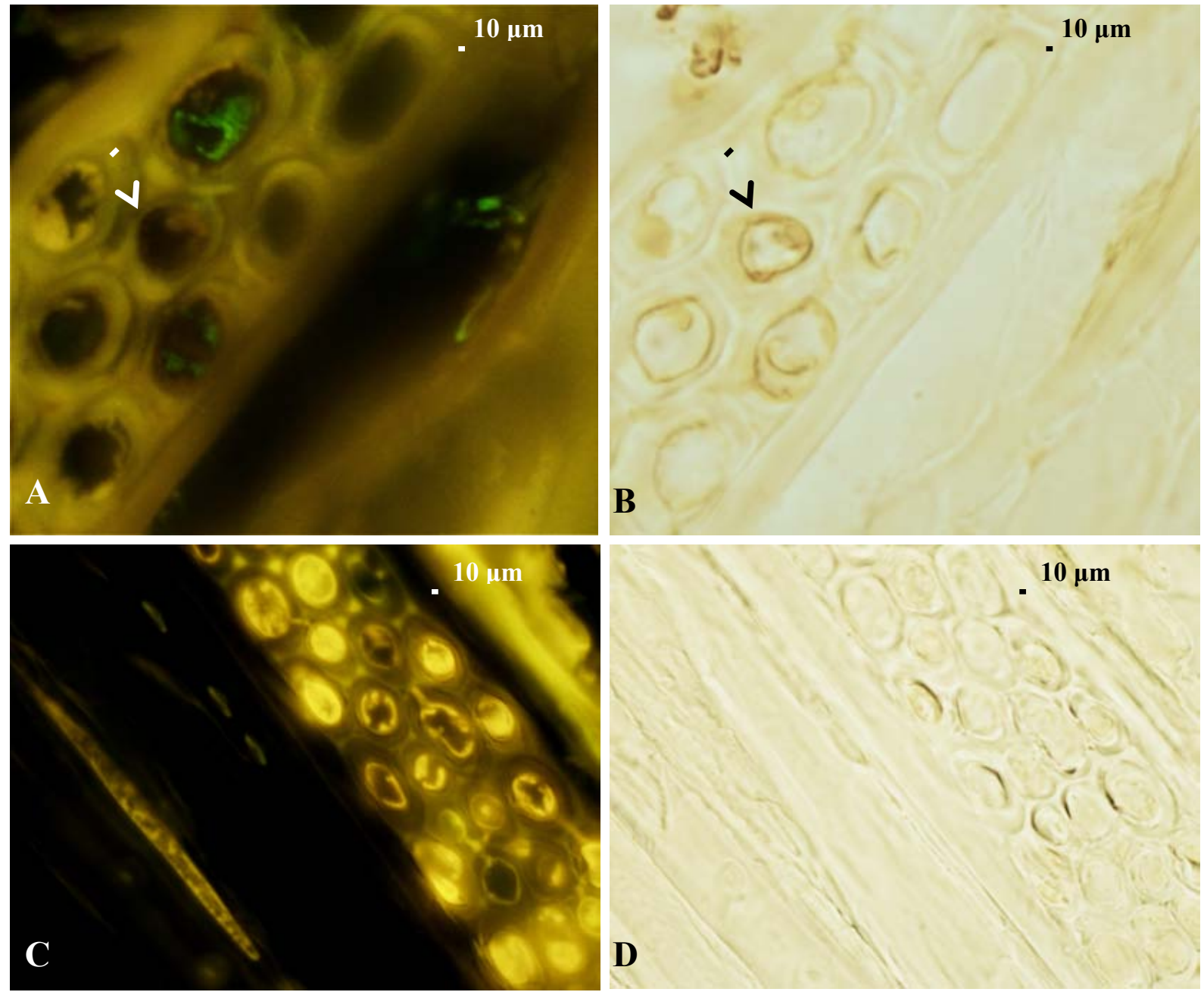

Fig. (2). Immunofluorescence of fungal melanin in cross section of parenchyma rays of Acer saccharum with melanized mycelium of Oxyporus populinus in fluorescence light (A) and in bright field (B); control samples of sugar maple in cross section of parenchyma rays with no fungal inoculation, in fluorescence light (C) and in bright field (D).
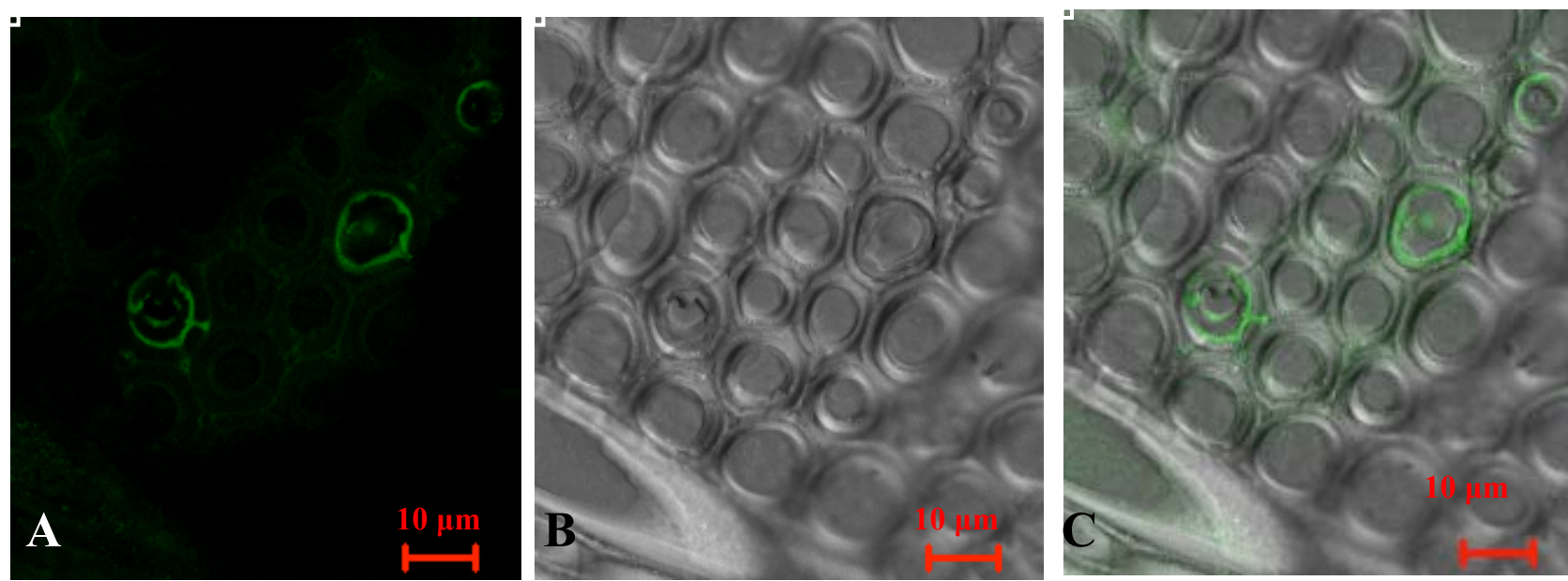

Fig. (3). Imaging of Acer saccharum ray parenchyma with melanized mycelium of Oxyporus populinus in cross section, obtained by confocal microscopy. (A) fluorescence image; (B) phase contrast image; (C) merged confocal image. 

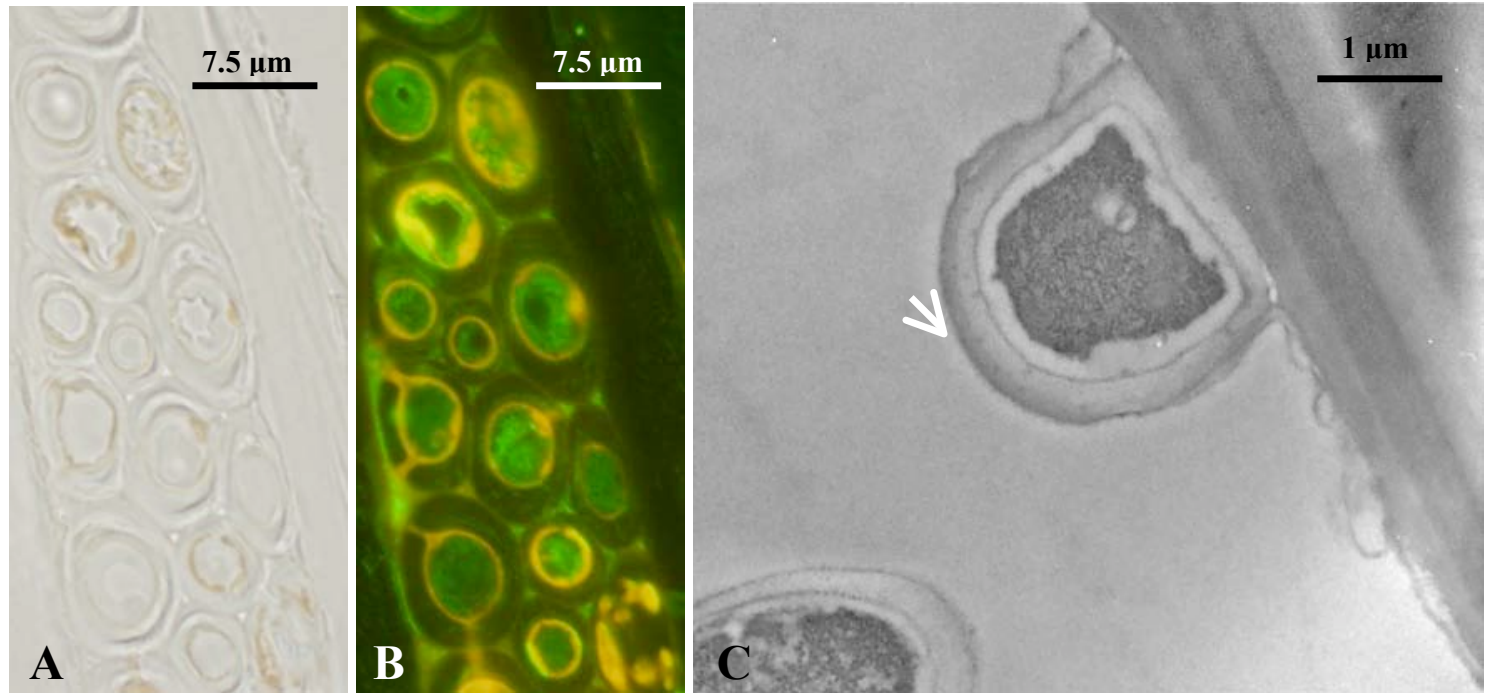

Fig. (4). Imaging of natural melanin produced by Fomes fomentarius in Betula alleghaniensis. (A) $-^{\circ}(\mathrm{C}-\mathrm{imaging}$ by light and (B)${ }^{\circ}$ (C)-immunofluorescence microscopy of cross section in ray cells of with melanin; (C) immunolabelling of melanin in TEM imaging of natural melanin produced by $F$. fomentarius.
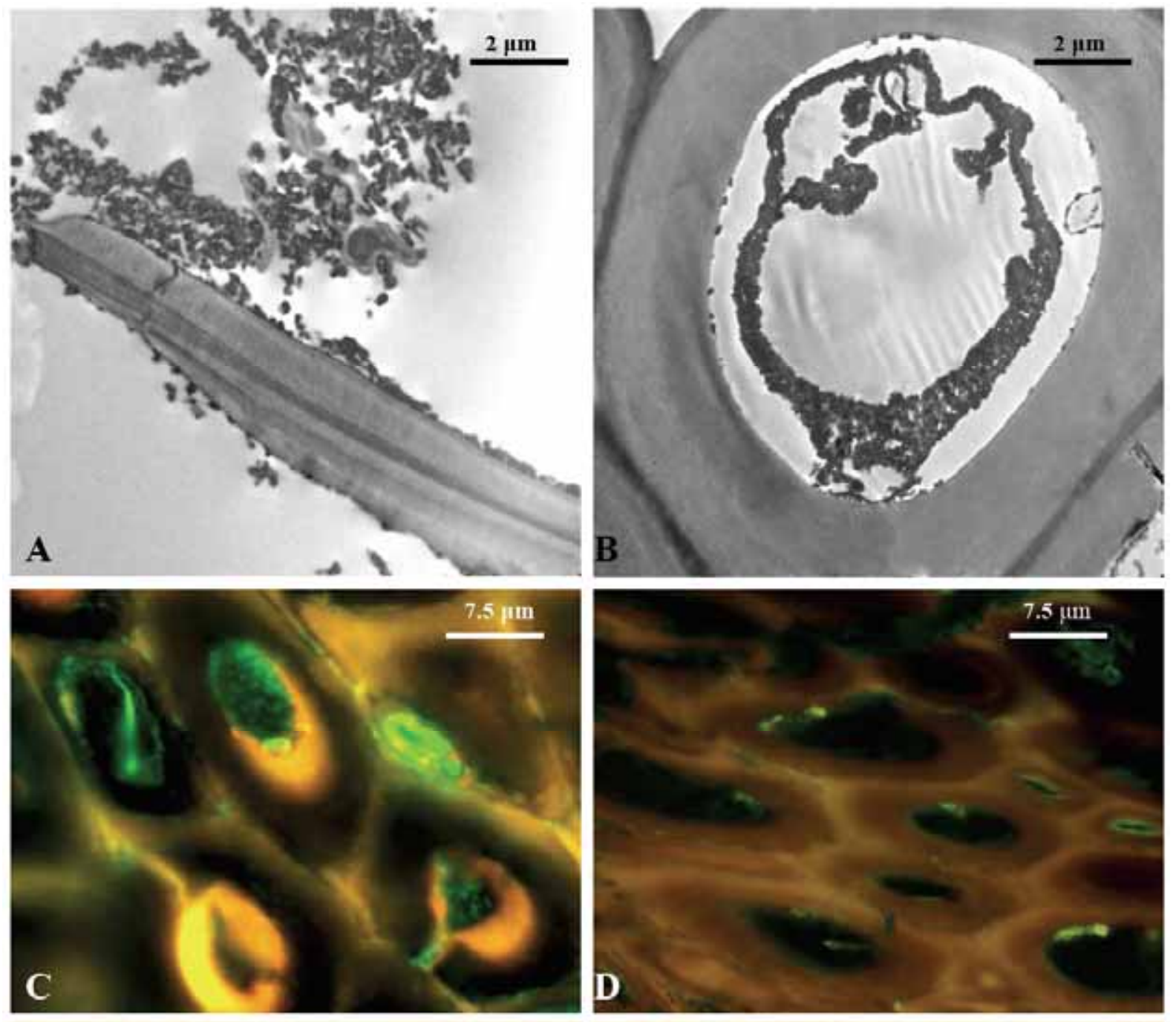

Fig. (5). Contd... 

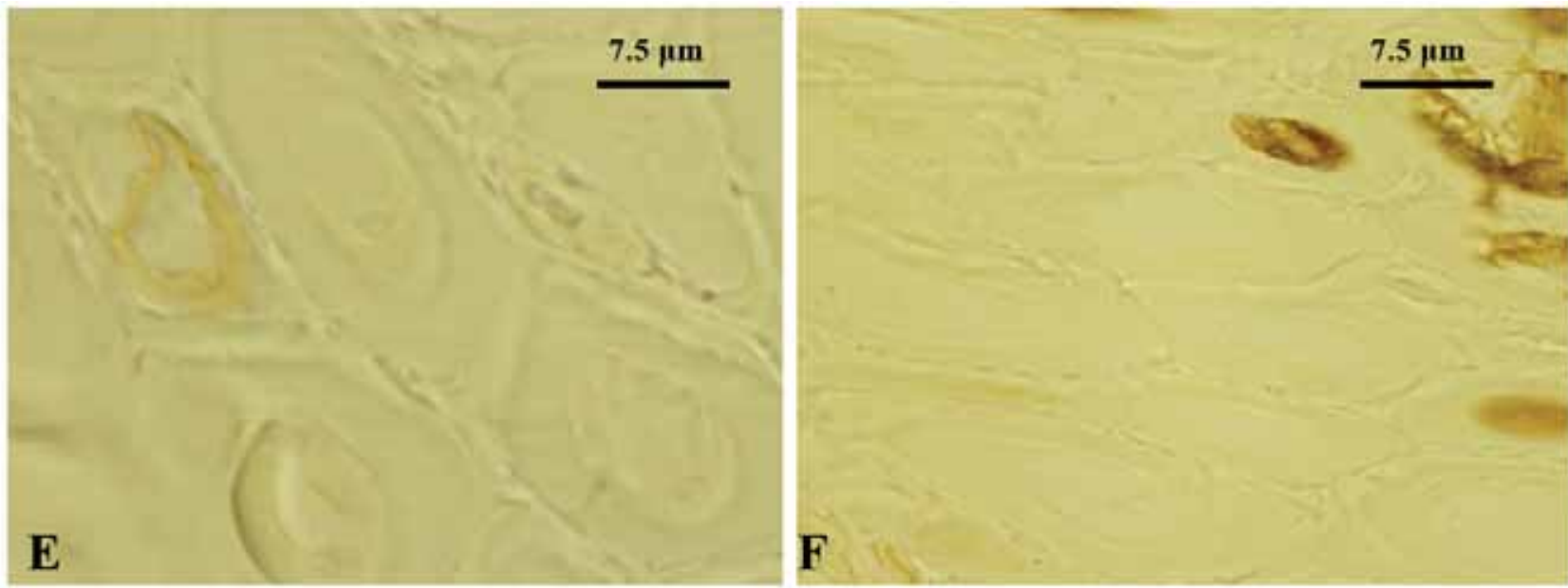

Fig. (5). Imaging by TEM (a and b), and immuno-FL of Acer saccharum with melanin produced by T. versicolor (A), (C) and (E) in monoculture and (B), (D) and (F) pretreated with catechol before fungal inoculation; (A) - TEMimage of cross section of wood vessels ; (B) TEM image of cross section in wood tracheids; (C) and (D) -fluorescence image of cross section in wood tracheids with melanin; (E) and (F) - LM image of cross section in wood tracheids.
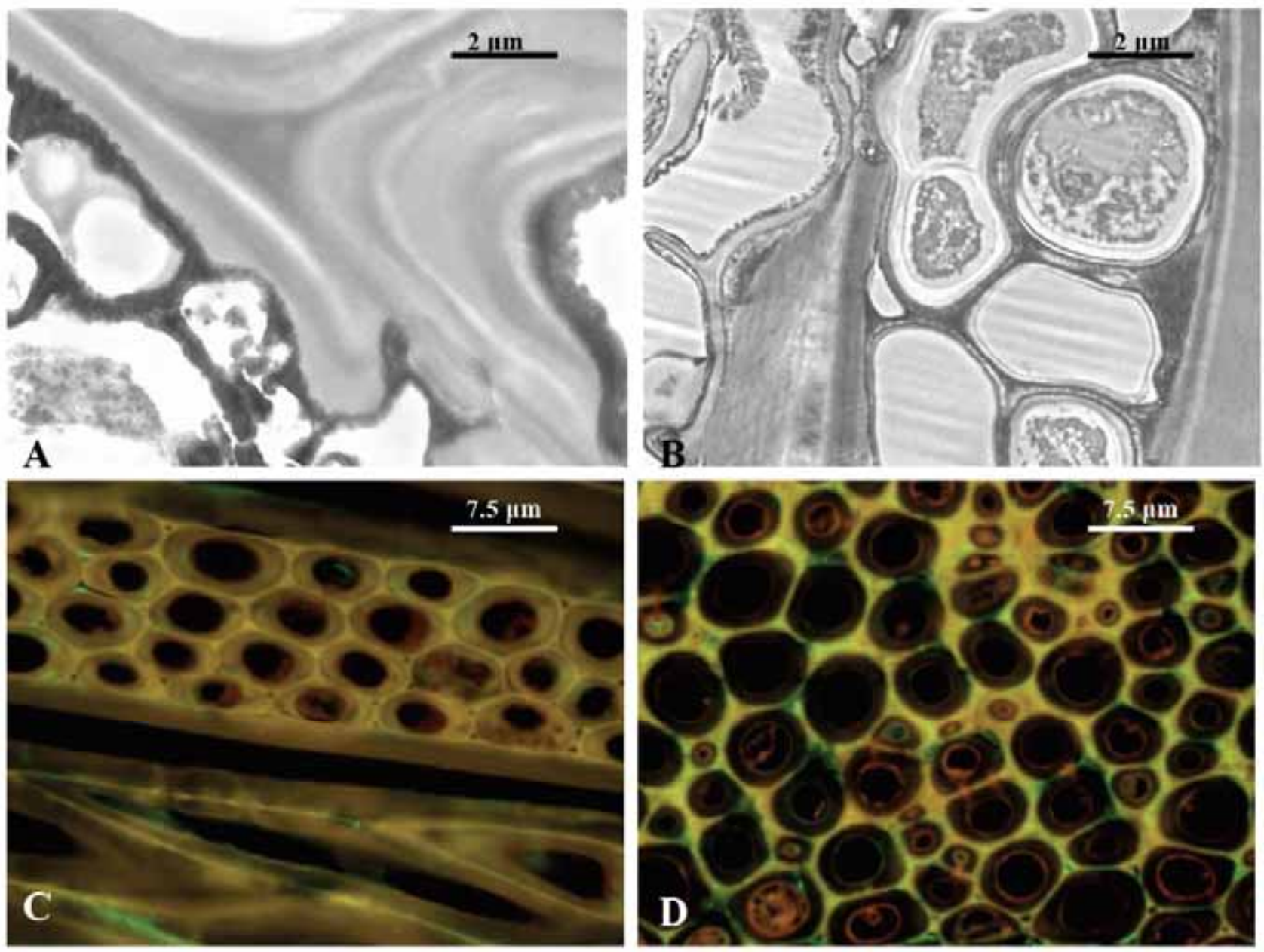

Fig. (6). Contd... 


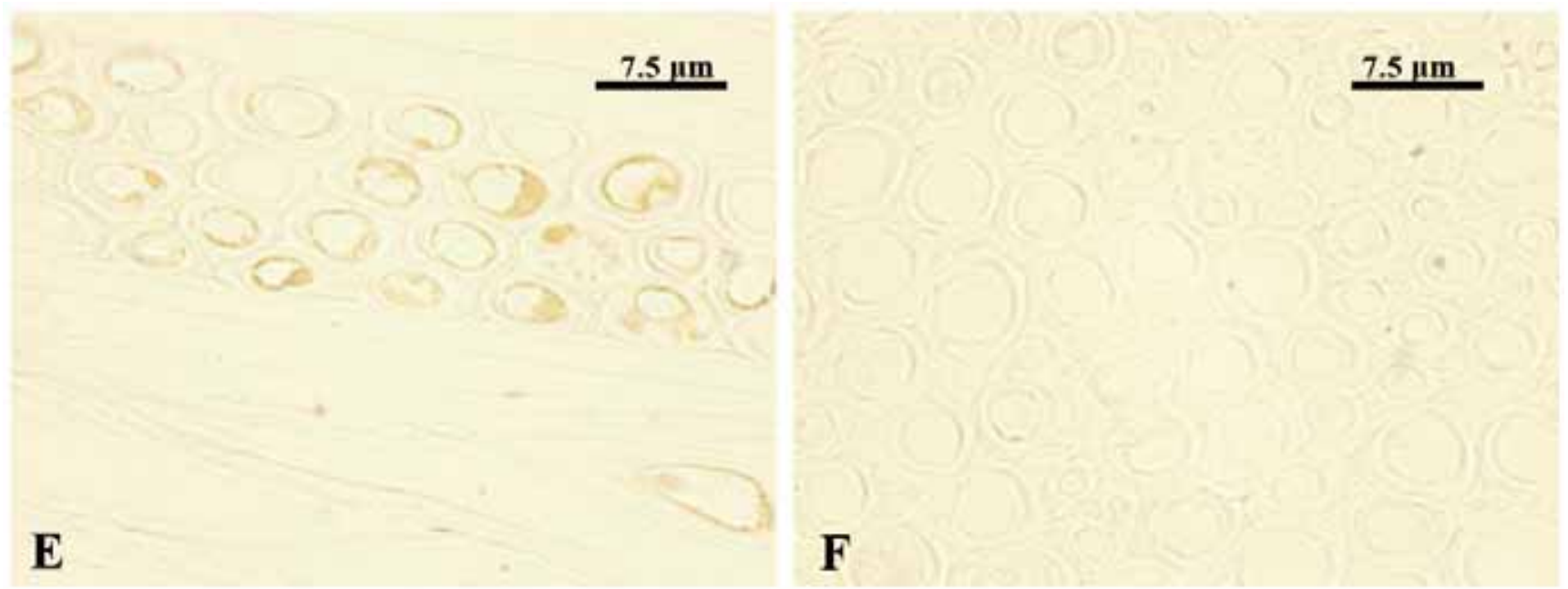

Fig. (6). Imaging by TEM (a and b), and immuno-FL of Fagus grandifolia with melanin produced by T. versicolor (A), (C), (E) in monoculture, and (B), (D), (F) pretreated with catechol before fungal inoculation; (A), (B) - TEM images of cross section of tracheids; (C) and (D) - immunofluorescence images of cross section in wood ray cells with melanin; (E) and (F) - LM image of cross section in wood tracheids.
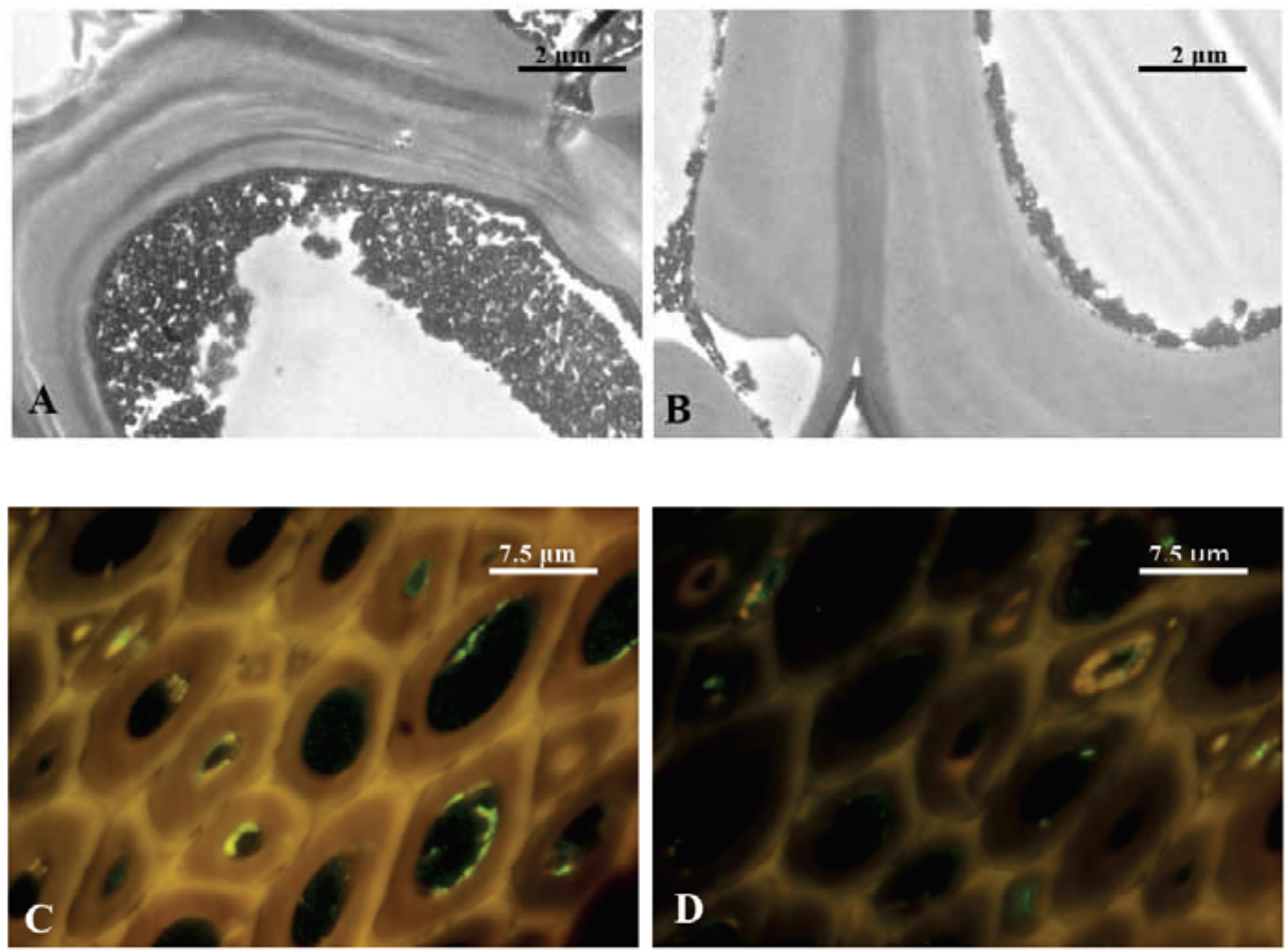

Fig. (7). Contd... 

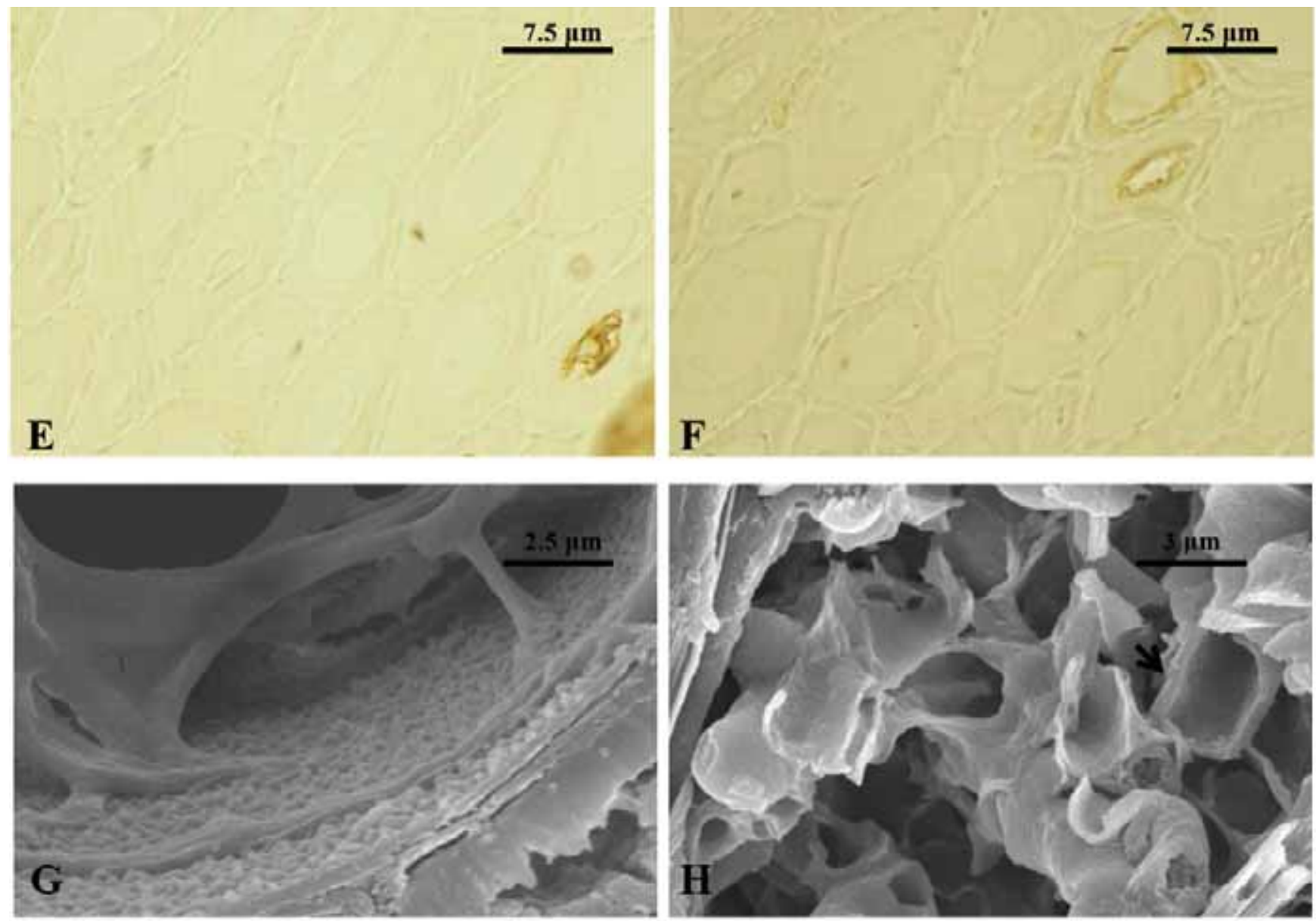

Fig. (7). Imaging of Acer saccharum (A, C and E) and in Fagus grandifolia (B, D and F with melanin produced by X. polymorpha; (A) and (B) TEM imaging of tracheids in cross section; (C) and (D) immunofluorescence imaging of tracheids in cross section; (E) and (F) LM imaging of tracheids in cross section; (G) - SEM of Acer saccharum cross section with melanin layer deposition on the cell wall of the wood vessel; (H) - longitudinal section on Acer saccharum tracheid filled with hollow melanized mycelium (arrow).

Table 2. Summary of the microscopy methods and results obtained from the study of Op $=$ Oxyporus populinus, Xp $=$ Xylaria polymorpha, $\mathrm{Tv}=$ Trametes versicolor, $\mathrm{Ff}=$ Fomes fomentarius $; \mathrm{Ih}=$ Inonotus hispidus, in $\mathrm{SM}=$ sugar $\mathbf{m a p l e}, \mathrm{B}=\mathrm{beech}, \mathrm{Bi}=$ birch.

\begin{tabular}{|c|c|c|c|c|}
\hline $\begin{array}{c}\text { Sample Type } \\
\text { Fungus/wood/treatment }\end{array}$ & Staining & Immunolabeling & Microscopy Method & Results \\
\hline $\mathrm{Xp} / \mathrm{Sm}, \mathrm{Xp} / \mathrm{B}, \mathrm{Tv} / \mathrm{SM}, \mathrm{Tv} / \mathrm{B}$ & Silver staining & - & LM & Unspecific binding to wood tissue \\
\hline $\mathrm{Op} / \mathrm{SM}$ & Alexa Fl 488 & $\begin{array}{c}\text { Mab6D2 } \\
\text { (primary antibody) } \\
\text { Gold conjugate secondary } \\
\text { antibody }\end{array}$ & $\begin{array}{l}\text { LM, SEM, TEM } \\
\text { FL, CM }\end{array}$ & $\begin{array}{l}\text { Two types of melanin deposits, rugose } \\
\text { surface of melanin } \\
\text { Immunolabeling of melanin, selective } \\
\text { binding of melanin antibody }\end{array}$ \\
\hline Tv/SM, Tv/SM/catechol & Alexa Fl 488 & $\begin{array}{c}\text { Mab6D2 } \\
\text { (primary antibody) }\end{array}$ & $\begin{array}{l}\text { LM, TEM } \\
\text { FL }\end{array}$ & $\begin{array}{l}\text { Two types of melanin deposits, rugose } \\
\text { surface of melanin } \\
\text { Immunolabeling of melanin, selective } \\
\text { binding of melanin antibody }\end{array}$ \\
\hline Tv/B, Tv/B/catechol & Alexa Fl 488 & $\begin{array}{l}\text { Mab6D2 } \\
\text { (primary antibody) Gold } \\
\text { conjugate secondary } \\
\text { antibody }\end{array}$ & $\begin{array}{l}\text { LM, TEM } \\
\text { FL }\end{array}$ & $\begin{array}{c}\text { Morphologic differences of melanin } \\
\text { deposition in SM and B; same type of } \\
\text { melanin deposits in treated-untreated wood } \\
\text { Immunolabeling of melanin }\end{array}$ \\
\hline
\end{tabular}


Table 2. contd...

\begin{tabular}{|c|c|c|c|c|}
\hline $\begin{array}{c}\text { Sample Type } \\
\text { Fungus/wood/treatment }\end{array}$ & Staining & Immunolabeling & Microscopy Method & Results \\
\hline \hline $\mathrm{Xp} / \mathrm{SM}, \mathrm{Xp} / \mathrm{B}$ & Alexa Fl 488 & $\begin{array}{c}\text { Mab6D2 } \\
\text { (primary antibody) Gold } \\
\text { conjugate secondary } \\
\text { antibody }\end{array}$ & $\begin{array}{c}\text { LM, TEM, SEM } \\
\text { FL }\end{array}$ & $\begin{array}{c}\text { Two types of melanin deposits, rugose } \\
\text { surface of melanin } \\
\text { Immunolabeling of melanin }\end{array}$ \\
\hline $\mathrm{Ff} / \mathrm{Bi}$ & Alexa FL 488 & $\begin{array}{c}\text { Mab6D2, } \\
\text { Gold conjugate secondary } \\
\text { antibody, }\end{array}$ & LM, TEM \\
FL & $\begin{array}{c}\text { One type of gregarious melanin deposits, no } \\
\text { layer along the wood cells walls } \\
\text { Immunolabeling of melanin granule and at } \\
\text { the fungal cell walls level }\end{array}$ \\
\hline $\mathrm{Ih} / \mathrm{SM}$ & - & $\begin{array}{c}\text { Mab6D2 } \\
\text { Gold conjugate secondary } \\
\text { antibody }\end{array}$ & $\begin{array}{c}\text { Two types of melanin deposits, } \\
\text { Immunolabeling of melanin granule and at } \\
\text { the fungal cell walls level }\end{array}$ \\
\hline
\end{tabular}

secretion of phenols into the external environment where they are oxidized by autolysis [2]. The wall-bound melanin, found in hyphae most melanized fungi, and in conidia and sclerotial cell walls, forms various patterns of electron-dense granules, and may occur in the outer or inner part of the fungal cell walls [7, 12, 13, 35-38]. The production of fungal pigmentation minimizes the degradation of wood cells [2], ensuring the structural integrity of the melanized layer.

In this research we observed at least three general yet distinctive types of melanin assembly in fully developed zone line formations in spalted wood: the granules produced extracellularly by fungal cells, forming the melanin layer that binds with wood cell walls; the extracellular melanin layer that forms the sclerotial hyphae of $O$. populinus, $T$. versicolor and $X$. polymorpha (Fig. 1 and Fig. 3); and the melanin particle produced internally by fungal cells in the case of F. fomentarius and I. hispidus. However, based on the variation of the wood substrate composition, different mechanisms of melanin assembly could be observed within the same fungal species.

The morphological variation of melanin assembly in different wood substrates reported in this research might explain the various chemical structures previously reported for fungal melanin [33, 39-41] as well as for the multiple genes identified in melanin biogenesis [21, 42-45]. Melanin deposits produced in vitro by $T$. versicolor in sugar maple tended to be attached to the wood cell walls, while in the same substrate pretreated with catechol, those bindings seemed sparse (Fig. 5). This was not the case in beech, where $T$. versicolor was not influenced by catechol treatment in regard to pigmentation pattern and melanin assembly (Fig. 6). There is strong evidence that the structure of melanin produced by this fungus varies with the nature of the wood substrate, which can directly influence the existing chemical bonds with the wood polysaccharides along the wood cell walls, as demonstrated by Zhong et al. [40]. There is yet no indication how and if the structural functions of those chemical bonds have any influence on the melanin properties. Many reported melanin analyses fail to demonstrate the chemical bonds between melanin and wood cell walls, due to treatment with harsh chemicals during extraction [46]. In the same context, Simon and Ito [47] argued that in the natural environment, melanins are associated with proteins and metal ions bound to the functional groups of the biopolymers, which influence the overall structure of these melanin formations, and can also determine the morphology of melanins assembly.

The most consistent morphology of melanin formation within the wood substrate was noted in X. polymorpha, which is in agreement with the findings reported by Campbell [4]. As expected, the fungus developed decay cavities specific to white rot fungi, more noticeable in beech, and the wood cells within the zone line formations contained small melanin granules that formed a layer firmly bound to the wood cell walls, as well as melanized hyphae (Fig. 7). In contrast, no melanin granule depositions were observed along the wood lumen in the case of zone line formation in birch colonized by $F$. fometarius. Immunolabeling with melanin antibody of fungal mycelium in birch wood indicated melanin activity within the fungal cell walls (Fig. 4A and B). However, immunolocalization with melanin antibody could not be clearly differentiated within the dense dark organelles formed in the hyphal cells (Fig. 4C). The mature zone lines formed by $F$. fometarius were assembled from conglomerates of intracellular melanized hyphae within the wood cells and the precise pattern of hyphal melanization was not clear from this investigation. The lack of melanin deposits along the wood cell lumen was also supported by the similar description of decay and pigmentation of $F$. fometarius given by Schwarze et al. [48].

Other distinct patterns of pigmentation were observed in the case of I. hispidus. There are two known phenolic pigments produced by $I$. hispidus identified by extraction analysis: the brown pigment hispidin characterized by Edwards et al. [49] and Klaar and Steglich [50], and a much lighter brown-yellow metabolite known as hispolon [51]. It was hypothesized that hispidin may polymerize during maturation of the fungi and its development is increased by 

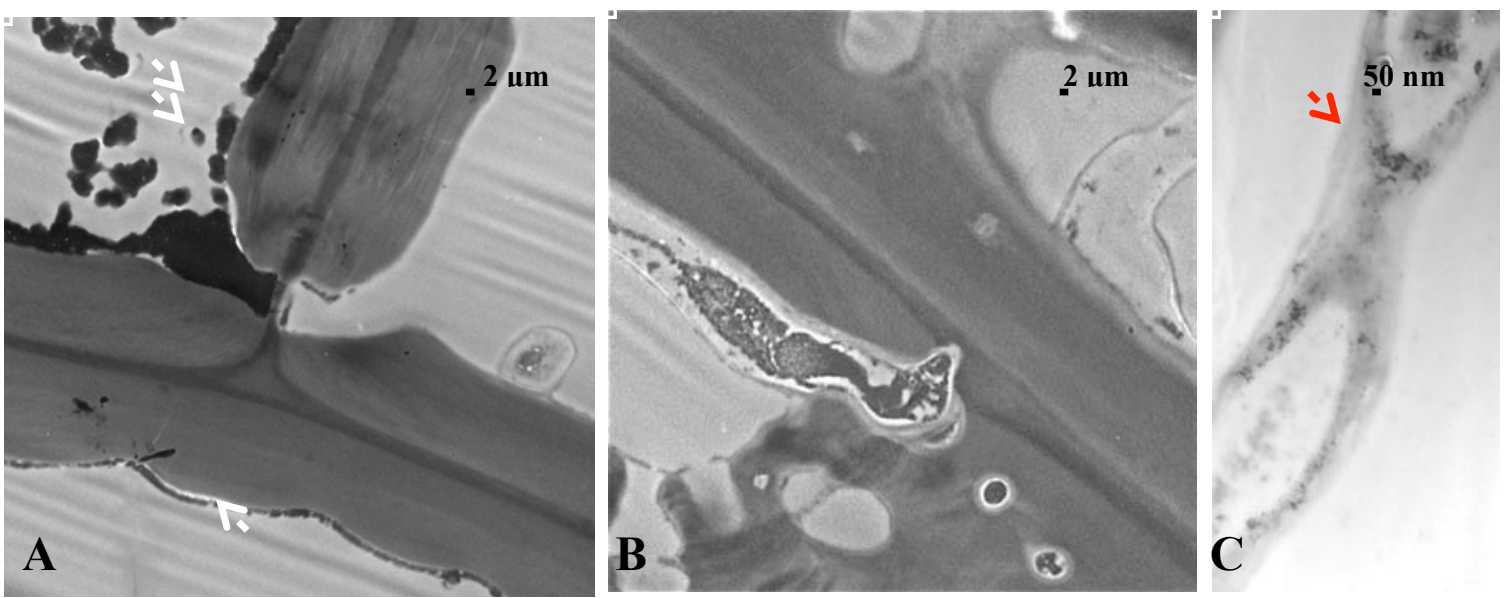

Fig. (8). Immunolabeling of melanin produced by I. hispidus in Acer saccharum. (A) - TEM imaging of cross section of Acer saccharum tracheid cells with melanin granule deposition; (B) - TEM imaging of cross section of Acer saccharum tracheid cells with melanized hyphae; (C) - TEM imaging tangential section of fungal hyphae with melanin formations in hyphal cell wall (arrow).

exposure to light $[52,53]$. Two distinctive types of layered pigment deposition along the wood cell walls were observed, each assembled from granules up to $200 \mathrm{~nm}$ and $850 \mathrm{~nm}$ respectively, as well as melanization within the hyphal cell wall (Fig. 8A, B). The specific pigmented layers might be the result of the bi-modal nature of pigment production by $I$. hispidus.

The distinctive melanin structures and assemblies produced by the wood inhabiting fungi that were studied indicate that an accurate description of chemical structure of fungal melanin is not possible by aggressive extraction methods. The fact that each fungus is capable of producing multiple melanin-type pigment structures at any given time should be accounted for.

The immunolabeling of fungal melanin in wood substrates using the silver enhancement technique was not successful, possibly due to nonspecific binding to the wood substrates by silver particles used in our protocol. The melanin antibody mostly labeled zones with incipient melanin formation, whereas dense melanized layers exposed by sectioning were not immunolabeled.

\section{CONCLUSION}

The results of this research indicate a bi- or multi-modal activity of melanin production and assembly by woodinhabiting fungi, and identify possible variations in melanin formation mechanisms, influenced by both the fungal and wood species involved in the process. Immunolabeling with an available melanin antibody confirmed the melanin nature of the pigments produced by $O$. populinus, $T$. versicolor, $X$. polymorpha, F. fomentarius, and I. hispidus. Future research of fungal melanin chemical structure should focus on nondestructive analysis methods combined with advanced imaging techniques.

\section{CONFLICT OF INTEREST}

The authors confirm that this article content has no conflict of interest.

\section{ACKNOWLEDGEMENTS}

This work comes from the first author's $\mathrm{PhD}$ thesis works.

\section{REFERENCES}

[1] Anagnost SE, Worrall JJ, Wang CJK. Diffuse cavity formation in soft rot of pine. Wood Sci Technol 1994; 28(3): 199-208.

[2] Bell AA, Wheeler MH. Biosynthesis and function of fungal melanins. Ann Rev Phytopathol 1986; 24: 441-51.

[3] Butler MJ, Gardiner RB, Day AW. Degradation of melanin or inhibition of its synthesis: are these a significant approach as a biological control of phytopathogenic fungi. Biol Control 2005; 32: 326-36.

[4] Campbell AH. Zone lines in plant tissues. I. The black lines formed by Xylaria polymorpha (Pen.) Grev. in hardwoods. Ann Appl Biol 1933; 20: 123-44.

[5] Campbell AH. Zone line in plant tissues: II. The black lines formed By Armillariamellea (Vahl) Quel. Ann Appl Biol 1934; 21: 1-22.

[6] Campbell AH, Munson RG. Zone Lines In Plant Tissues. III. The Black Lines Formed By Polyporussquamosus(Htjds.) Fr. Ann Appl Biol 1936; 23(3): 453-64.

[7] Wheeler MH, Tolmstoff WJ, Meola S. Ultrastructure of melanin formation in Verticillium dhaliae with (+) scytalone as a biosynthetic intermediate. Can J Microbiol 1976; 22: 702-11.

[8] Casadevall A, Rosas AL, Nosanchuk JD. Melanin and virulence in Cryptococcus neoformans. Curr Opin Microbiol 2000; 3: 354-358

[9] Thathachari YT. Structure of melamine. In: VJ McGovern, Basel, S Karger, P Russell Eds. Pigment Cell 1. 1973; pp. 158-64.

[10] Thathachari YT. Spatial Structure of melamine. In: VJ McGovern, Basel, S Karger, P Russell Eds. Pigment Cell 3. 1976; pp. 64-8.

[11] Rosas AL, Nosanchuk JD, Gómez BL, Edens WA, Henson JM, Casadevall A. Isolation and serological analyses of fungal melanins. J Immunol Methods 2000; 244(1-2): 69-80

[12] Ellis DH, Griffiths DA. The location and analysis of melanins in the cell walls of some soil fungi. Can J Microbiol 1974; 20: 137986.

[13] Ellis DH, Griffiths DA. Melanin deposition in the hyphae of a species of Phomopsis. Can J Microbiol 1975; 21: 442-152.

[14] Bell AA, Puhalla JE, Tolmsoff WJ, Stipanovic RD. Use of mutants to establish (+)-scytalone as an intermediate in melanin biosynthesis. Can J Microbiol 1976; 22: 787-99.

[15] Hegnauer H, Nyhlén LE, Rast DM. Ultrastructure of native and synthetic Agaricus bisporus melanins-implications as to the compartmentation of melanogenesis in fungi. Exp Mycol 1985; 9: $1-29$.

[16] Wheeler MH, Bell AA. Melanins and their importance in pathogenic fungi. Curr Top Med Mycol 1988; 2: 338-7. 
[17] Butler MJ, Lachance MA. Inhibition of melanin synthesis in the black yeast Phaeococcomyces sp. by growth on low $\mathrm{pH}$ ascorbate medium: production of spheroplasts from "albinized" cells. Can J Microbiol 1987; 33: 184-7.

[18] Bull AT. Kinetics of cellulase inactivation by melanin. Enzymologia 1970; 39: 333-47.

[19] Nicolaus RA, Piattelli M, Fattorusso E. The structure of melanins and melanogenesis-IV on some Natural Melanins. Tetrahedron 1964; 20: 1163-1172

[20] Caesar-Tonthat T, Ommen KFV, Geesey GG, Henson JM. Melanin production by a filamentous soil fungus in response to copper and localization of copper sulfide by sulfide-silver staining. Appl Environ Microbiol 1995; 61: 1968-75.

[21] Henson JM, Butler MJ, Day AW. The Dark Side of the Mycelium: Melanins of Phytopathogenic Fungi. Annu Rev Phytopathol 1999; 37: 447-71.

[22] Ammeyer A, Oomen LA, Pavel S. Preparation of monoclonal mouse antibodies against two specific eumelanin related compounds. J Immunol Methods 1992; 156(1): 61-7.

[23] Liu J, Jibow K. Development and characterization of a murine monoclonal antibody against phaeomelanin and its precursor5-Scysteinyldopa. Melanoma Res 1993; 3: 463-9.

[24] Asadevall A, Scharff MD. The mouse antibody response to infection with Cryptococcus neoformans: VH and VL usage in polysaccharide binding antibodies. J Exp Med 1991; 174: 151-60.

[25] Polacheck I, Kwon-Chung KJ. Melanogenesis in Cryptococcus neoformans. Microbiology 1988; 134(4): 1037-41.

[26] Nosanchuk JD, Casadevall A. Cellular charge of Cryptococcus neoformans: Contributions from the capsular polysaccharide, melanin , and monoclonal antibody binding. Infect Immunol 1997; 65(5): 1836-41.

[27] Cherniak R, Sundstrom JB. Minireview: Polysaccharide antigens of the capsule of Cryptococcus neoformans. Infect Immun 1994; 62(5): 1507-12.

[28] Nosanchuk JD, Rosas AL, Casadevall A. The antibody response to fungal melanin in mice. J Immunol 1998; 160(12): 6026-31.

[29] Osanchuk JD, Valadon P, Feldmesser M, Casadevall A. Melanization of Cryptococcus neoformans in murine infection. Mol Cell Biol 1999; 19(1): 745-50.

[30] Carzaniga R, Fiocco D, Bowyer P, O'Connell RJ. Localization of melanin in conidia of Alternaria alternata using phage display antibodies. Mol Plant Microbe In 2002; 15(3): 216-24.

[31] Rosas AL, MacGill RS, Nosanchuk JD, Kozel TR, Casadevall A. Activation of the Alternative Complement Pathway by Fungal Melanins. Clin Diagn Lab Immun 2002; 9(1): 144-8.

[32] Dadachova E, Casadevall A. Melanin as a potential target for radionuclide therapy of metastatic melanoma. Future Oncol 2005; 1(4): 541-9.

[33] Dadachova E, Bryan RA, Huang X, et al. Ionizing radiation changes the electronic properties of melanin and enhances the growth of melanized fungi. PloS one 2008; 2(5): e457.

[34] Robinson SC. Developing fungal pigments for 'painting' vascular plants. Appl Microbiol Biotechnol 2012; 93(4): 1389-94.
[35] Pirt SJ, Rowley B. Melanin production in Aspergillus nidulans. Biochem J 1969; 14: 9P-10P.

[36] Jones D. Ultrastructure and composition of the cell walls of Sclerotinia sclerotiorum. T Brit Mycol Soc 1970; 54(3): 351-60.

[37] Benítez T, Villa TG, GarcíaAcha I. Some chemical and structura features of the conidial wall of Trichoderma viride. Can J Microbiol 1976; 22(2): 318-21.

[38] Jackson GVH, Gay JL. Perennation of Sphaerothecamorsuvae as cleistothecia with particular reference to microbial activity. T Brit Mycol Soc 1976; 66(3): 463-71.

[39] Tian S, Garcia-rivera J, Yan B, Casadevall A, Stark RE. unlocking the molecular structure of fungal melanin using $13 \mathrm{c}$ biosynthetic labeling and solid-state NMR. Biochemistry 2003; 42(27): 8105-9.

[40] Zhong J, Frases S, Wang H, Casadevall A, Stark RE. Following fungal melanin biosynthesis with solid-state NMR: biopolymer molecular structures and possible connections to cell-wall polysaccharides. Biochemistry 2008; 47(16): 4701-10.

[41] Casadevall A, Nakouzi A, Crippa PR, Eisner M. Fungal melanins differ in planar stacking distances. PloS one 2012; 7(2), e30299.

[42] Williamson PR. Laccase and melanin in the pathogenesis of Cryptococcus neoformans. Front Biosci 1997; 2(19): e99-e107.

[43] Kimura N, Tsuge T. Gene cluster involved in melanin biosynthesis of the filamentous fungus Alternaria alternata. J Bacteriol 1993 175(14): 4427-35.

[44] Woo PCY, Tam EWT, Chong KTK, et al. High diversity of polyketide synthase genes and the melanin biosynthesis gene cluster in Penicillium marneffei. FEBS J 2010; 277(18): 3750-8.

[45] Wang H-L, Breuil C. A second reductase gene involved in melanin biosynthesis in the sap-staining fungus Ophiostoma floccosum. Mol Genet Genomics 2002; 67(5): 557-63.

[46] Butler MJ, Day AW, Henson JM, Money NP. Pathogenic Properties of Fungal Melanins. Mycologia 2001; 93(1): 1-8.

[47] Simon JD, Ito S. Response to the chemical structure of melanin by Cheun WL. Pigment Cell Res 2004; 17(4): 423-4.

[48] Schwarze FWMR, Engels J, Mattheck C. (2000) Fungal Strategies of Wood Decay in Trees. Translated by Linnard W., SpringerVerlag, Berlin, Heidelberg, New York

[49] Edwards RL, Lewis DG, Wilson DV. (1961) Constituents of the higher fungi. Hispidin, a new 4-hydroxy-6-styryl-2-pyrone from Polyporus hispidus (Bull.) Fr. J Chem Soc 4995-5002.

[50] Klaar M, Steglich W. Isolierung von Hispidin und 3,14'Bihispidinyl aus Phelinus pomaceus (Poriales). Chem Bet 1977; 110: 1058-62

[51] Ali NAA, Jansen R, Pilgrim H, Liberra K, Lindequist U. Hispolon, A yellow pigment from Inonotus hispidus. Phytochemistry 1996; 41(3): 927-9.

[52] Nambudiri AMD, Vance CP, Towers GHN. Effect of light on enzymes of phenylpropanoid metabolism and hispidin biosynthesis in Polyporus hispidus. Biochem J 1973; 134: 891-7.

[53] Vance CP, Tregunna EB, Nambudiri AMD, Towers GHN Styrylpyrone biosynthesis in Polyporus hispidus. I. Action spectrum and photoregulation of pigment and enzyme formation. Biochim Biophys Acta 1974; 343: 138-47.

(C) Tudor et al.; Licensee Bentham Open.

This is an open access article licensed under the terms of the Creative Commons Attribution Non-Commercial License (http://creativecommons.org/ licenses/by-nc/3.0/), which permits unrestricted, non-commercial use, distribution and reproduction in any medium, provided the work is properly cited 